CONCISE REPORT

\title{
Trabecular bone mass and bone formation are preserved after limb immobilisation in p53 null mice
}

\author{
R Okazaki, A Sakai, A Ootsuyama, T Sakata, T Nakamura, T Norimura
}

Ann Rheum Dis 2004;63:453-456. doi: 10.1136/ard.2003.011643

Objectives: To determine whether disruption of the p53 gene leads to preservation of trabecular bone volume (BV) after limb immobilisation.

Materials and methods: Tibias of immobilised hind limbs of p53 gene knockout $\left(\mathrm{p} 53^{-/-}\right)$and wild-type $\left(\mathrm{p} 53^{+/+}\right)$mice were compared. Right knee joints of 8 week old mice were immobilised in full extension for 7 days. Trabecular structure and bone formation were similar in the $\mathrm{p} 53^{-/-}$and $\mathrm{p} 53^{+/+}$ control groups.

Results: Immobilisation significantly reduced BV to $77 \%$ of

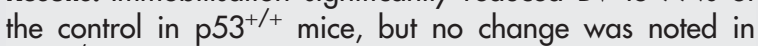
$\mathrm{p} 53^{-1-}$ mice. After immobilisation, bone formation rate was significantly reduced in $\mathrm{p} 53^{+/+}$but not in $\mathrm{p} 53^{-/-}$mice. In bone marrow cell cultures the numbers of alkaline phosphatase positive colony forming units-fibroblastic and mineralised nodules were significantly reduced by immobilisation in $\mathrm{p}^{5} 3^{+/+}$but not in $\mathrm{p} 53^{-/-}$mice. Immobilisation enhanced

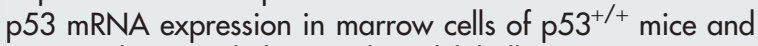
increased terminal dUTP nick end labelling positive osteocytes and marrow cells in $\mathrm{p} 53^{+/+}$but not in $\mathrm{p} 53^{-/-}$mice. Lack of p53 in immobilised mice was associated with preservation of trabecular bone mass and bone formation and suppression of significant apoptosis of marrow cells.

Conclusion: Disruption of the p53 gene preserves trabecular bone mass and leads to bone formation after limb immobilisation.

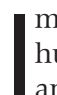
mmobilisation of limbs induces local bone loss in humans $^{1}$ and animals. ${ }^{2}$ Immobilised experimental animals simulate conditions of disuse of bones, such as paralysis, plaster cast application, and long term bed rest. It has been shown that bone loss in paraplegic patients $^{1}$ and sciatic neurectomised mice ${ }^{2}$ is due to increased bone resorption as well as reduced bone formation. Bone formation decreased 7-14 days after immobilisation. ${ }^{2}$ The underlying mechanism(s) of rapid reduction of bone formation after limb immobilisation has not been elucidated.

p53 Expression as well as apoptosis is observed in bone marrow cells. ${ }^{3}$ Apoptosis has also been seen in osteocytes. ${ }^{4}$ We proposed that intracellular p53 has an important role in trabecular bone turnover and in bone marrow cell development after immobilisation. Specifically, we suggested that rapid reduction of trabecular bone mass, and bone formation after limb immobilisation, are closely related to facilitation of p53 signalling in bone marrow cells. In this study we investigated the effects of p53 gene status on trabecular bone turnover and bone marrow cell development after immobilisation in p53 gene knockout $\left(\mathrm{p}_{53^{-/-}}\right)$mice and $\mathrm{p} 53$ wild-type $\left(\mathrm{p} 53^{+/+}\right)$ mice.

\section{MATERIALS AND METHODS Experimental design}

The $\mathrm{p} 53^{-1-}$ mice were homozygous for the p53 gene disruption, as described previously. ${ }^{5}$ Wild-type mice of the parental wild-type inbred strain were used as $\mathrm{p} 53^{+/+}$mice. The experimental protocol was approved by the Ethics Review Committee for Animal Experimentation of the University of Occupational and Environmental Health. Eight week old male $\mathrm{p} 53^{+/+}$and $\mathrm{p} 53^{-/-}$mice were respectively assigned to two groups matched for body weight (groups 1 and 2 for $\mathrm{p} 53^{+/+}$mice and groups 3 and 4 for $\mathrm{p} 53^{-/-}$ mice; $\mathrm{n}=32$ in each group) after 1 week's acclimatisation. Mice of groups $1\left(\mathrm{p} 53^{+/+}+\mathrm{C}\right)$ and $3\left(\mathrm{p} 53^{-/-}+\mathrm{C}\right)$ were mobilised normally as age matched controls. The right hind limbs of mice of groups $2\left(\mathrm{p} 53^{+/+}+\mathrm{IM}\right)$ and $4\left(\mathrm{p} 53^{-/-}+\mathrm{IM}\right)$ were immobilised for 7 days in full extension with a bandage tape, as described previously. ${ }^{6}$

\section{Histomorphometric analysis}

Histomorphometric analysis was described previously. ${ }^{2}$ Four groups comprising five mice each were studied. Abbreviations for histomorphometric parameters were derived from the recommendations of the American Society for Bone and Mineral Research Histomorphometry Nomenclature Committee, ${ }^{8}$ as follows: BV/TV, trabecular bone volume to tissue volume (\%); Tb.N, trabecular number $(/ \mathrm{mm})$; Tb.Th, trabecular thickness $(\mu \mathrm{m}) ; \mathrm{BFR} / \mathrm{BS}$, bone formation rate to bone surface ( $\mu \mathrm{m}-\% /$ day). The right tibias of five mice in each group were stained by the terminal dUTP nick end labelling (TUNEL) assay, as described previously. ${ }^{6}$ We measured the secondary spongiosa in the proximal tibia.

\section{Evaluation of bone marrow cells}

Twelve mice in each group were killed on day 7 of immobilisation/control. Six tibias in each group were used for the colony forming units-fibroblastic (CFU-f) assay, while the other six were used for the measurement of mineralised nodule formation, as described previously. ${ }^{27}$

\section{Evaluation of mRNA expression in bone marrow cells} Reverse transcriptase-polymerase chain reaction (RT-PCR) amplification

Four groups comprising five mice each were treated as described above. mRNA was isolated from the tibial bone marrow cells and PCR amplification was performed, as described previously. ${ }^{7}$ Specific PCR primers were designed from published sequences of murine $\mathrm{p} 53^{9}$ and $\beta$-actin. ${ }^{10}$ The

Abbreviations: AP, alkaline phosphatase; $B V$, bone volume; $C F U-f$, colony forming units-fibroblastic; RT-PCR, reverse transcriptasepolymerase chain reaction; TGF, transforming growth factor; TUNEL, terminal dUTP nick end labelling 
PCR products were $517 \mathrm{bp}(\mathrm{p} 53)$ and $632 \mathrm{bp}$ ( $\beta$-actin) in fragment sizes.

\section{Statistical analysis}

Results are expressed as the mean (SD). Differences between groups were examined for statistical significance using the Mann-Whitney $U$ test. A value of $\mathrm{p}<0.05$ denoted the presence of a significant difference.

\section{RESULTS}

\section{Body weight and tibial size}

Body weight increased in all four groups 7 days after the start of the experiment (data not shown), and the body weight gain was similar in these groups. No significant differences were seen in the length and diameter of the tibias among the four groups (data not shown).

\section{Trabecular bone volume, structure, and bone formation}

Table 1 shows that $\mathrm{BV} / \mathrm{TV}$ in $\mathrm{p} 53^{+/+}+\mathrm{IM}$ was significantly reduced to about $77 \%$ of the level of $\mathrm{p} 53^{+/+}+\mathrm{C}$. Tb.N in p $53^{+/+}+\mathrm{IM}$ was significantly decreased compared with that in $\mathrm{p} 53^{+/+}+\mathrm{C}$. On the other hand, BV/TV and Tb.N did not differ between $\mathrm{p} 53^{-1-}+\mathrm{C}$ and $\mathrm{p} 53^{-1-}+\mathrm{IM}$. There were no significant differences in Tb.Th among the four groups. BFR/BS was significantly lower in $\mathrm{p} 53^{+/+}+\mathrm{IM}$ than in $\mathrm{p} 53^{+/+}+\mathrm{C}$. However, $\mathrm{BFR} / \mathrm{BS}$ in $\mathrm{p} 53^{-1-}+\mathrm{IM}$ was maintained at a similar level to that in $\mathrm{p} 53^{-1-}+\mathrm{C}$. There was no difference between the control groups of $\mathrm{p} 53^{+/+}$and $\mathrm{p} 53^{-/-}$mice.

\section{Bone marrow cells}

Disruption of the p53 gene and immobilisation did not change the numbers of total CFU-f (data not shown). Immobilisation significantly decreased the numbers of alkaline phosphatase (AP) positive CFU-f, and mineralised nodule formation in cultured bone marrow cells from p $53^{+/+}$mice compared with control mice (table 1). However, there were no significant differences in the numbers of AP positive CFU-f and nodule formation between $\mathrm{p}^{5} 3^{-/-}+\mathrm{C}$ and p $53^{-/-}+\mathrm{IM}$.

\section{mRNA expression}

Immobilisation enhanced (about 1.8 times) p53 mRNA expression in bone marrow cells from $\mathrm{p} 53^{+/+}$mice compared with the level in the control group (fig 1).

\section{TUNEL assay}

In $\mathrm{p} 53^{+/+}+\mathrm{IM}, 5.4(1.3) \%$ of osteocytes in trabecular bone were stained by the TUNEL method (fig 2A). However, in $\mathrm{p} 53^{+/+}+\mathrm{C}, \mathrm{p} 53^{-/-}+\mathrm{C}$, and $\mathrm{p} 53^{-/-}+\mathrm{IM}$, no osteocytes were stained (fig 2B).

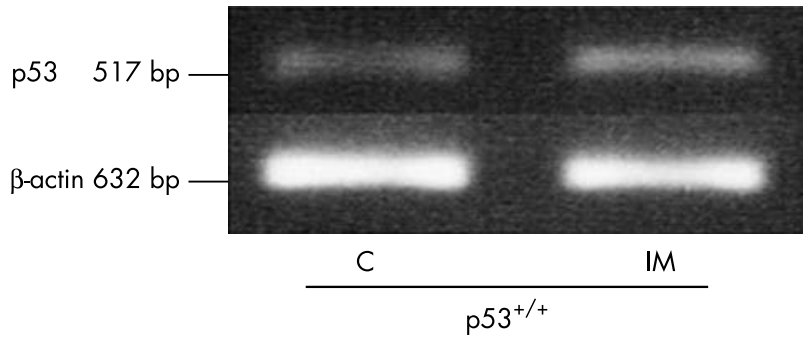

Figure 1 p53 mRNA expression in bone marrow cells. Representative data are shown. C, control; IM, immobilised group.

In $\mathrm{p} 53^{+/+}$mice the frequency of TUNEL positive bone marrow cells as well as osteocytes significantly increased in the immobilised group compared with the control group (fig 2C). However, there was no significant difference in TUNEL positive bone marrow cells between $\mathrm{p} 53^{-1-}+\mathrm{C}$ and $\mathrm{p} 53^{-/-}+\mathrm{IM}$.

\section{DISCUSSION}

We demonstrated the presence of TUNEL positive osteocytes in $\mathrm{p} 53^{+/+}$mice after immobilisation, but not in $\mathrm{p} 53^{-/-}$mice. Previous studies reported that cell death in the femur of glucocorticoid treated rabbits, affecting osteoblasts and osteocytes, comprised up to half of the BV and was consistent with apoptosis. ${ }^{11}$ Furthermore, in this study, we showed an increased proportion of TUNEL positive bone marrow cells in $\mathrm{p}^{5} 3^{+/+}$mice after immobilisation, coincident with increased levels of p53 mRNA. These results are in agreement with the results of our previous studies showing increased p53 mRNA levels in bone marrow cells from hind limbs of $\mathrm{p}^{5} 3^{+/+}$mice after tail suspension. ${ }^{7}$ They are also similar to the report of Ke et al, which showed that p53 expression induced by an oestrogen agonist/antagonist was localised in apoptotic cells in rat bone marrow. ${ }^{12}$ Considered together, these results indicate that limb immobilisation induces p53 related apoptosis of osteocytes and bone marrow cells.

We recently reported that articular cartilage degenerates after immobilisation in $\mathrm{p} 53^{+/+}$mouse knees, but not in $\mathrm{p} 53^{-/-}$knees, and that apoptotic cells are present in articular cartilage in the femur and tibia of $\mathrm{p} 53^{+/+}$mice after immobilisation. ${ }^{6}$ We previously showed that bone loss due to mechanical unloading is closely related to facilitation of intracellular p53-p21 signalling. ${ }^{7}$ On the other hand, immobilisation induces transforming growth factor (TGF) $\beta 1$ in synovial fluid. ${ }^{13}$ TGF $\beta 1$ is essential for rapid $\mathrm{p} 53$ mediated cellular responses, which decide cellular fate. ${ }^{14}$ The

\begin{tabular}{|c|c|c|c|c|}
\hline & \multicolumn{2}{|l|}{$\mathrm{p} 53^{+/+}$} & \multicolumn{2}{|l|}{$\mathrm{p} 53^{-/-}$} \\
\hline & Control & IM & Control & IM \\
\hline $\begin{array}{l}\text { BV/TV }(\%) \\
\text { Tb.N }\left(/ \mathrm{mm}^{2}\right) \\
\text { Tb.Th }(\mu \mathrm{m}) \\
\text { BFR/BS }(\mu \mathrm{m}-\% / \text { day) } \\
\text { AP positive CFU-f (No/culture) } \\
\text { Mineralised nodule formation (\% of } \\
\text { dish area) }\end{array}$ & $\begin{array}{l}12.3(0.7) \\
4.4(0.3) \\
28.1(1.7) \\
39.4(3.5) \\
40.2(4.9) \\
92.5(4.1)\end{array}$ & $\begin{array}{l}9.5(0.9)^{*} \\
3.7(0.5)^{*} \\
28.5(1.7) \\
22.7(1.9)^{*} \\
30.3(4.9)^{*} \\
71.3(10.7)^{*}\end{array}$ & $\begin{array}{l}13.1(1.2) \\
4.7(0.5) \\
30.9(1.4) \\
41.0(4.1) \\
46.5(5.1) \\
90.3(7.0)\end{array}$ & $\begin{array}{l}12.4(0.8) \dagger \\
4.5(0.2) \dagger \\
31.6(3.5) \\
36.3(3.0) \dagger \\
54.5(3.0) \dagger \\
94.4(3.9)\end{array}$ \\
\hline \multicolumn{5}{|c|}{$\begin{array}{l}\text { Data are presented as the mean (SD) of five to six mice. } \\
{ }^{*} \mathrm{p}<0.05 \mathrm{v} \text { control } \mathrm{p} 53^{+++} ; \mathrm{t}<0.05 \text { versus immobilised } \mathrm{p} 53^{+/+} \text {mice, by the Mann-Whitney } \mathrm{U} \text { test. The values of } \\
\text { control } \mathrm{p} 53^{-/-} \text {are not significantly different from those of control } \mathrm{p} 53^{+/+} \text {. } \\
\mathrm{BV} / \mathrm{TV} \text {, bone volume to tissue volume; Tb.N, trabecular number; Tb.Th, trabecular thickness; BFR/BS, ratio of bone } \\
\text { formation rate to bone surface; AP positive CFU-f: alkaline phosphatase positive colony formation unit-fibroblast. }\end{array}$} \\
\hline
\end{tabular}



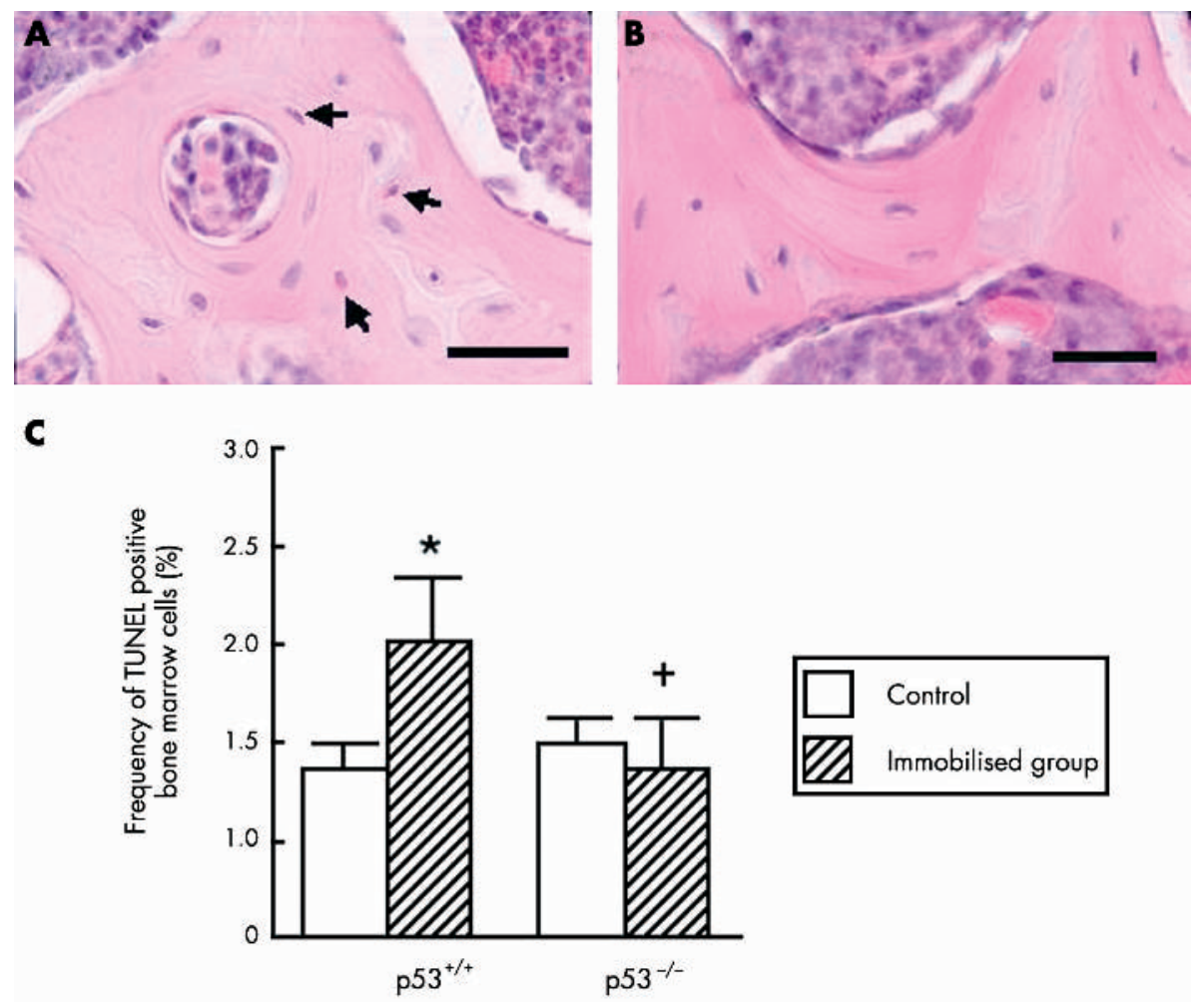

Figure 2 TUNEL staining of the trabecular bone of (A) $\mathrm{p} 53^{+/+}$and (B) $\mathrm{p} 53^{-/-}$mice obtained at 7 days after immobilisation. Arrows indicate TUNEL positive osteocytes. Scale bar $=50 \mu \mathrm{m}$. Each tissue section was finally counterstained with haematoxylin and eosin. (C) Proportion of TUNEL positive

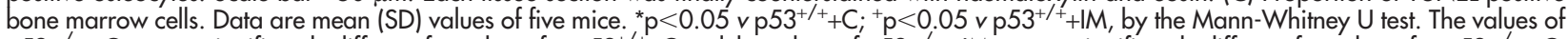
$\mathrm{p} 53^{-/-}+\mathrm{C}$ are not significantly different from those for $\mathrm{p} 53^{+/+}+\mathrm{C}$ and the values of $\mathrm{p} 53^{-/-}+\mathrm{IM}$ are not significantly different from those for $\mathrm{p} 53^{-/-}+\mathrm{C}$.

TGF $\beta 1-p 53-p 21$ pathway may be the critical role of signal transduction in bone marrow cells after immobilisation.

Bone marrow cell culture studies showed that immobilisation of ${\mathrm{p} 53^{+/+}}^{+}$mice markedly reduced the number of AP positive CFU-f, and mineralised nodule formation, although there was no significant difference in total CFU-f between $\mathrm{p} 53^{+/+}+\mathrm{C}$ and $\mathrm{p} 53^{+/+}+\mathrm{IM}$. These results suggest that immobilisation could suppress the osteogenic cells at mature stages of osteogenic differentiation in vitro. Previous studies in the hind limb elevation model also showed that skeletal unloading inhibited the proliferation and differentiation of rat osteoprogenitor cells in vitro. ${ }^{15}$ These results suggest that intracellular p53 signalling enhanced by immobilisation leads to apoptosis of osteogenic progenitors or mature osteoblasts.

In conclusion, disruption of the p53 gene preserved bone formation and trabecular bone mass.

\section{ACKNOWLEDGEMENTS}

This work was supported in part by grants from the Ministry of Education, Science, Sports, and Culture of Japan (Scientific Research B 11470315 to AS and Scientific Research B 12470313 and Scientific Research on Priority Areas B 12137210 to TN).

\section{Authors' affiliations}

R Okazaki, A Ootsuyama, T Norimura, Department of Radiation Biology and Health, School of Medicine, University of Occupational and Environmental Health, Kitakyushu, Japan

A Sakai, T Sakata, T Nakamura, Department of Orthopaedic Surgery, School of Medicine, University of Occupational and Environmental Health, Kitakyushu, Japan
Correspondence to: Dr A Sakai, Department of Orthopaedic Surgery, School of Medicine, University of Occupational and Environmental Health, 1-1 Iseigaoka, Yahatanishi-ku, Kitakyushu 807-8555, Japan; a-sakai@med.uoeh-u.ac.jp

Accepted 10 July 2003

\section{REFERENCES}

1 Chappard D, Minaire P, Privat C, Berard E, Mendoza-Sarmiento J,

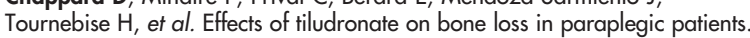
J Bone Miner Res 1995;10:112-18.

2 Sakai A, Nakamura T, Tsurukami H, Okazaki R, Nishida S, Tanaka Y, et al. Bone marrow capacity for bone cells and trabecular bone turnover in immobilized tibia after sciatic neurectomy in mice. Bone 1996;18:479-86.

3 Wlodarski P, Wasik M, Ratajczak MZ, Sevignani C, Hoser G, Kawiak J, et al. Role of p53 in hematopoietic recovery after cytotoxic treatment. Blood 1998;91:2998-3006.

4 Weinstein RS, Jilka RL, Parfitt AM, Manolagas SC. Inhibition of osteoblastogenesis and promotion of apoptosis of osteoblasts and osteocytes by glucocorticoids. Potential mechanisms of their deleterious effects on bone. J Clin Invest 1998;102:274-82.

5 Norimura T, Nomoto S, Katsuki M, Gondo Y, Kondo S. p53-dependent apoptosis suppresses radiation-induced teratogenesis. Nat Med 1996:2:577-80.

6 Okazaki R, Sakai A, Ootsuyama A, Sakata T, Nakamura T, Norimura T. Apoptosis and p53 expression in chondrocytes relate to degeneration in articular cartilage of immobilized knee joints. J Rheumatol 2003;30:559-66

7 Sakai A, Sakata T, Tanaka S, Okazaki R, Kunugita N, Norimura T, et al. Disruption of the p53 gene results in preserved trabecular bone mass and bone formation after mechanical unloading. J Bone Miner Res 2002; 17:1 19-27.

8 Parfitt AM, Drezner MK, Glorieux FH, Kanis JA, Malluche H, Meunier PJ, et al Bone histomorphometry: standardization of nomenclature, symbols, and units. Report of the ASBMR Histomorphometry Nomenclature Committee. J Bone Miner Res 1987;2:595-610.

9 Will K, Warnecke G, Bergmann S, Deppert W. Species- and tissue-specific expression of the $\mathrm{C}$-terminal alternatively spliced form of the tumor suppressor p53. Nucleic Acids Res 1995;23:4023-8. 
10 Lu L, Qian S, Hershberger PA, RudertWA, Lynch DH, Thomson AW. Fas ligand (CD95L) and B7 expression on dendritic cells provide counter-regulatory signals for T cell survival and proliferation. J Immunol 1997;158:5676-84.

11 Eberhardt AW, Yeager-Jones A, Blair HC. Regional trabecular bone matrix degeneration and osteocyte death in femora of glucocorticoid- treated rabbits. Endocrinology 2001;142:1333-40.

12 Ke HZ, Paralkar VM, Grasser WA, Crawford DT, Qi H, Simmons HA, et al. Effects of CP-336,156, a new, nonsteroidal estrogen agonist/antagonist, on bone, serum cholesterol, uterus and body composition in rat models. Endocrinology 1998;139:2068-76.
13 Okazaki R, Sakai A, Uezono Y, Ootsuyama A, Kunugita N, Nakamura T, et al. Sequential changes in transforming growth factor (TGF)- $\beta 1$ concentration in synovial fluid and mRNA expression of TGF- $\beta 1$ receptors in chondrocytes after immobilization of rabbit knees. J Bone Miner Metab 2001;19:228-35.

14 Ewan KB, Henshall-Powell RL, Ravani SA, Pajares MJ, Arteaga C, Warters R, et al. Transforming growth factor-1 mediates cellular response to DNA damage in situ. Cancer Res 2002;62:5627-31

15 Kostenuik PJ, Halloran BP, Morey-Holton ER, Bikle DD. Skeletal unloading inhibits the in vitro proliferation and differentiation of rat osteoprogenitor cells. Am J Physiol 1997;273:E1133-9.

\section{$\mathrm{ECHO}$}

\section{Boring work is a pain}

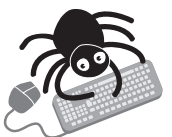

Please visit the Annals of the Rheumatic Diseases website [www. annrheumdis. com] for a link to the full text of this article. mployers might save their workers from work related pain and themselves from lost - productivity if they tried to alleviate monotony in the job, according to a prospective - cohort study. Load bearing tasks are known predictors of new pain-but are often unavoidable-whereas tackling boring or psychosocial areas of a job might give more scope for avoiding work related pain, its authors suggest.

Boring work comprising half or more of a job significantly predicted new onset shoulder pain (odds ratio 1.7) among more than 800 new employees from 12 occupational groups. So did heavy manual tasks such as lifting weights, pushing or pulling heavy weights, and working with hands above shoulder height, with odds ratios of 1.6-1.9. Pain occurred in the same proportion (around 15\%) at 12 and 24 months' follow up but varied among occupational groups.

The 803 pain free subjects (two thirds of them men) were followed up by questionnaire; $638(79 \%)$ responded at 12 months and $476(88 \%)$ at 24 months. All were new to the jobs market and were chosen from recruits to newly opened businesses; service or established businesses recruiting new employees, like police and fire services; and final year students of vocational courses like dentistry and nursing.

Studies have disagreed whether organisational or social facets of work are linked to new onset shoulder pain but almost all have been cross sectional. Enrolling new recruits in their first ever job avoided the healthy worker effect and meant that new onset pain really was new.

A Occupational and Environmental Medicine 2003;60:850-857. 